\title{
ISSUES IN MARKETING TO LOW-INCOME URBAN CONSUMERS: A CASE STUDY
}

\author{
Arthur T. Andersen*
}

\section{Introduction}

In recent years various aspects of the retail distribution system serving low-income segments of our society have been subjected to detailed study. The basic conclusion of this research is that too often the poor are poorly served. Recent work by the FTC's Bureau of Economics supports this conclusion. Products sold on credit by merchants specializing in serving lowincome customers are extremely costly. On the average, goods purchased for $\$ 100$ at wholesale sold for $\$ 255$ in low-income market stores ${ }^{1}$ compared with $\$ 159$ in general market stores. These comparisons are exclusive of credit charges.

Problems are apparent with respect to food distribution as well. Food marketing is notas well-organized in low-income areas as in newly developed suburban areas. ${ }^{2}$ The low-income consumer is more likely to do his shopping at a small, independent, "Mom and Pop" store. At the same time, those that shop in supermarkets have a limited range of choice. Not as many chains operate in the inner-city as in suburban areas. In the District of Columbia, one chain dominates. Moreover, indications are that this chain operates stores whose performance in the inner-city is inferior to those stores it operates in more competitive areas.

Much of the recent research into problems of low-income consumers has been motivated by charges of fraud, deception, and discrimination. ${ }^{3}$ Although such practices undoubtedly exist, for the most part they appear to be sporadic rather than systematic. Recent research findings of long-term significance relate to market imperfections. Retail markets serving low-income consumers are inadequately competitive. Until we can develop means to strengthen competitive forces, the problems arising from unequal access to earning opportunities will continue to be compounded by unequal consumer opportunities.

The balance of this paper is divided into three parts. The next section discusses certain key findings relating to food chain marketing in low-income areas of Washington, D. C. This is followed by a review, for the same city, of retail sales practices involving household furniture and appliances. Finally, views are presented as to the direction that continuing research into consumer problems of the poor should take.

\section{Supermarket Retailing in the Inner City}

Although the FTC first undertook to analyze food distribution practices in the District of Columbia because of charges of fraud and discrimination, special investigational surveys and hearings found no evidence that leading chainstore operators were employing discriminatory policies to exploit lowincome consumers. ${ }^{4}$ Nonetheless, food distribution in low-income areas is not free of problems. In fact, the manner in which food marketing is structured and presently functions supports a conclusion that consumers limiting their food purchases to inner-city, low-income areas will, on the average, pay more for food. 5

Basically, food marketing problems are rooted in poor market structure. 
In the first place, supermarkets do not have the same degree of market penetration in inner-city areas that they have in suburban areas. The low-income consumer is more likely to do his shopping at small, independent, "Mom and Pop" stores. Such stores generally charge higherprices whether located in low- or high-income a reas. 6

Secondly, few chains compete in the inner-city. Thus, low-income consumers' choice tends to be restricted as between differing chain operators This is significant when is is recognized that price policies among chains can differ markedly. Being able to choose between competing chains on the basis of general price policy can mean average savings of 5 to 10 percent of total food costs. In the D. C. area, the lowest priced supermarket chain operates no stores in the inner-city.

Most of the supermarkets in the low-income areas of the District of Columbia were operated by the same chain. ${ }^{7}$ The city's largest chain, Safeway, controlled 72 of the 99 supermarkets operated by the eight leading chains in the District of Columbia (Table 1). In the suburbs, Safeway controlled only 89 , or 34 percent, of the 259 supermarkets operated by the eight leading chains.

The very high concentration of supermarket ownership is even more evident in the low-income sections of the District of Columbia. In these areas, the leading chain, Safeway, operated 28 supermarkets, while a total of four other supermarkets were operated by three other chains. In other words, a single chain operated nearly 90 percent of the chain supermarkets in the low-income sections of the District of Columbia.

Finally, those supermarkets operating within the inner-city do not appear to perform as well as those in suburban areas in two important respects. First, they are less likely to be able to supply consumers with city-wide advertised specials. Secondly, in no instance were special price reductions put into effect in inner-city stores designed to counter the pressures of tough competition, whereas in certain suburban areas special price zones were established featuring price reductions on as many as 50 percent of surveyed items. These are perhaps the most important substantive findings presented in the Commission's recent Economic Report on Chain Store Selling Practices.

In the course of its investigation, the Commission staff undertook two major surveys of chainstore food pricing. The purpose of the surveys was to determine whether differential pricing patterns were evident among stores and, if so, whether such patterns were systematically related to the income level of customers served.

The first survey focused on pricing patterns for advertised items. Advertised price specials are a key element of merchandising for most supermarket chains. Margins on advertised specials generally are cut sharply and some industry experts have estimated that regular access to supermarket specials result in food cost savings of 5 to 10 percent. Thus, if price specials were not extended to low-income area stores, significant and unfavorable discrimination would result.

The advertised-price survey was designed to ascertain whether actual instore prices conformed to advertised prices; whether advertised items were in fact available for purchase; and, further, where price differentials between stores were found, whether such differentials had any apparent relationship to intensity of competition between stores or to income level of customers served. The survey included approximately 65 items with information tabulated for 75 stores. 


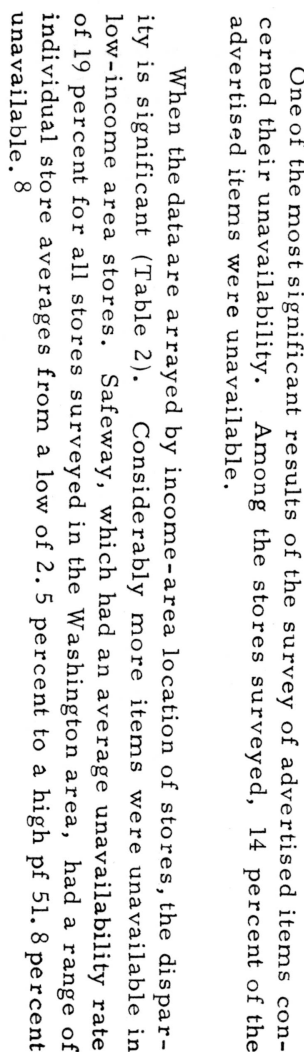

TABLE I. STORES OPERATED BY 4 AND 8 LEADING CHAINS IN WASHINGTON, D.C. , AND ITS SUBURBS, 1967

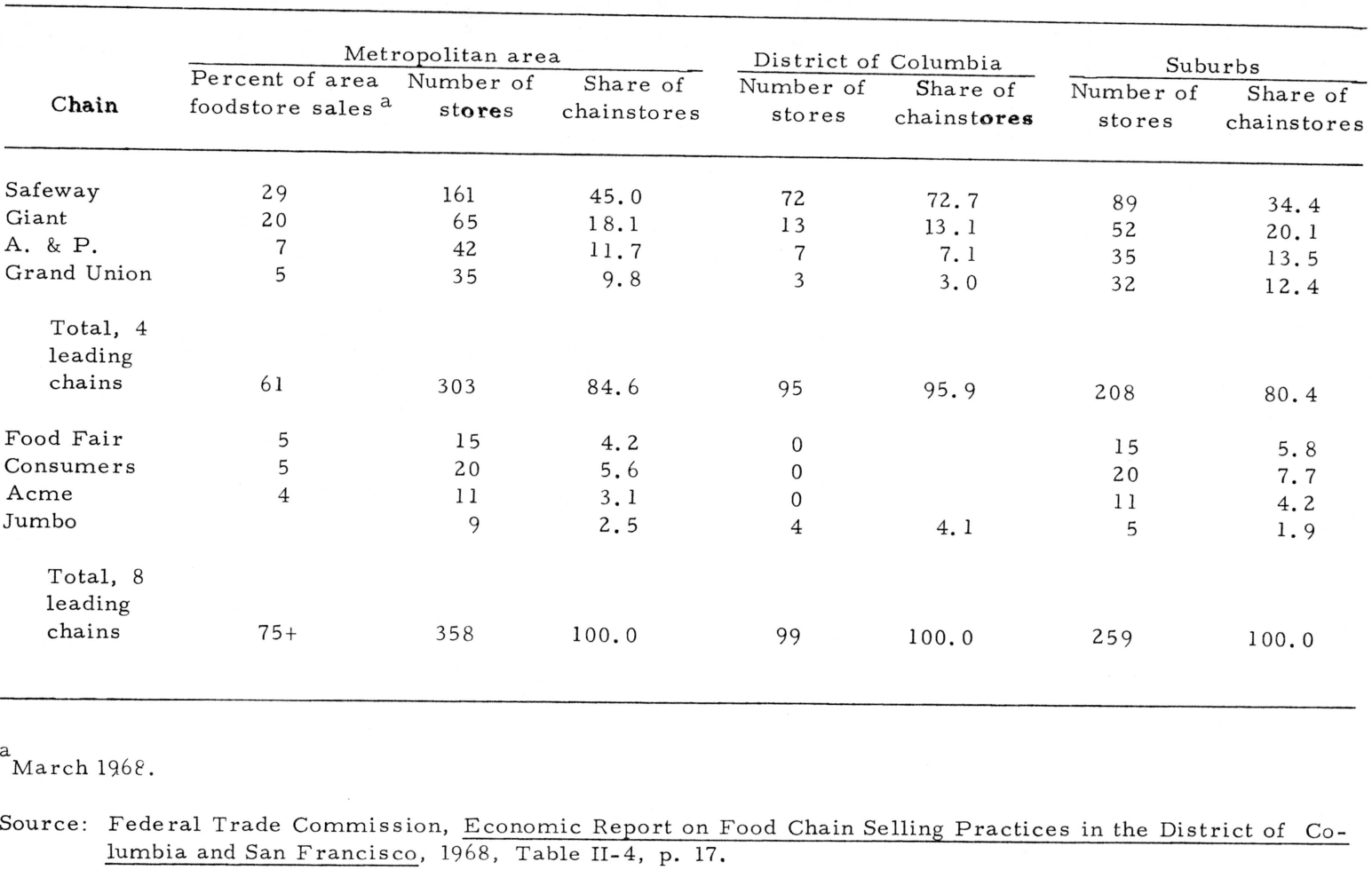


TABLE 2. PERCENT OF ADVERTISED SPECIAL ITEMS NOT FOUND IN STORES: A COMPARISON OF INNER-CITY LOW AND HIGHER INCOME AREA STORES AND SUBURBAN STORES OF THE WASHINGTON, D. C. METROPOLITAN AREA

\begin{tabular}{ccc}
\hline Location & Number of Stores & $\begin{array}{c}\text { Percent of } \\
\text { advertised specials } \\
\text { not found in stores }\end{array}$ \\
\hline Washington, D. C. (city) & 32 & 19.5 \\
Higher income areas & 12 & $12.7^{\mathrm{a}}$ \\
Low-income areas & 20 & $23.1^{\mathrm{b}}$ \\
Suburban areas & 43 & $10.2^{\mathrm{b}}$ \\
\hline
\end{tabular}

a difference this large in the frequency of advertised special i tems not found in stores could have occurred by chance less than 1 percent of the time in repeated sampling, had there been no actual difference in the availability of such items in the stores of the 2 areas.

b

A difference this great could have occurred by chance at least 100 percent of the time even though no difference existed in average availability rates of the areas. Therefore, the difference is not considered to be significant.

Source: Federal Trade Commission, Economic Report on Food Chain Selling Practices in the District of Columbia and San Francisco, 1968, Table IV-6, p. 31 .

Part of the out-of-stock pattern is associated with the fact that not all items are stocked in allstores. Smaller stores tend to carry a narrower line of products than do large stores. It is estimated that 30 percent of observed out-of-stock variability was associated with differences in store size. This statistical association may indicate a difficulty of smaller store managers to stock "specialized" items properly. On the other hand, out-of-stock variability may reflect a deliberate decision to avoid handling products that will tend to undermine a store's gross margin. At the very least, it appears questionable that central management has developed controls adequate to assure low rates of unavailability on advertised special items in all stores. The effectiveness of such controls as exist is weakest in stores located in low-income areas.

At the same time, it should be noted that the substantial difference between availability rates on advertiseditems in Washington in low-income and higher income area stores (23.1 and 12.7 percent, respectively) is not explained simply by smaller stores in the inner-city as a whole. Although higher income area stores within the city of Washington had a slightly higher unavailability rate than suburban stores, their unavailability rate was still nearly 50 percent lower than in the low-income area stores. Hence, low-income area shoppers in Washington, D. C. appear to be treated unfavorably in terms of the reduced availability of advertised items, as shown in Table 2 .

The second survey covered a specific market basket of goods. The items selected for inclusion were chosen to provide broad coverage of product categories and to include items regularly consumed by low-income families. The market basket listwas based on the foods surveyed by the Bureau of LaborStatistics for its Consumer Price Index. The list was tailored to fit each 
product.

The most interesting finding derived from this survey relates to the importance of competition in determining store pricing policies. No evidence of overt discrimination against low-income consumers is evident. Upward and downward deviations from authorized area price lists differ insignificantly among low- and high-income area stores (Table 3). The only significant deviations uncovered involved nine suburban stores in which significantly lower prices were in effect. Further study revealed that these stores were located in special competitive zones. None of these stores were located in low-income areas (Table 3). Thus, the benefits of price competition were most readily available to more affluenent consumers.

TABLE 3. DEVIATIONS IN PRICES OF MARKET BASKET ITEMS

A. Deviations for stores in normal marketing areas*

\begin{tabular}{|c|c|c|c|c|c|}
\hline \multirow{2}{*}{$\begin{array}{c}\text { Income area } \\
\text { of store }\end{array}$} & \multirow{2}{*}{$\begin{array}{l}\text { Number of } \\
\text { stores } \\
\text { surveyed }\end{array}$} & \multirow{2}{*}{$\begin{array}{c}\text { Percent of } \\
\text { items having } \\
\text { price } \\
\text { deviations }\end{array}$} & \multicolumn{3}{|c|}{$\begin{array}{c}\text { Percent of items having } \\
\text { price deviations } \\
\text { which were: }\end{array}$} \\
\hline & & & Higher & Lower & Other \\
\hline \multicolumn{6}{|l|}{ Washington, D. C.: } \\
\hline Low income & 21 & 5.9 & 3.0 & 2.6 & 0.3 \\
\hline Higher income & 80 & 7.2 & 3.3 & 3.7 & 0.2 \\
\hline Total & 101 & 6.9 & 3.2 & 3.5 & 0.2 \\
\hline
\end{tabular}

B. Deviations for stores in special competitive zones ${ }^{* *}$

\begin{tabular}{|c|c|c|c|c|}
\hline \multirow{2}{*}{$\begin{array}{c}\text { Food Chain } \\
\text { Identification of store }\end{array}$} & \multirow{2}{*}{$\begin{array}{l}\text { Percent of } \\
\text { items having } \\
\text { price deviations }\end{array}$} & \multicolumn{3}{|c|}{$\begin{array}{c}\text { Percent of items having } \\
\text { price deviations } \\
\text { which were: }\end{array}$} \\
\hline & & Higher & Lower & Othe $r^{a}$ \\
\hline \multicolumn{5}{|l|}{ Safeway: } \\
\hline Store A & 47.5 & 43.4 & 4.1 & 0.0 \\
\hline Store B & 40.8 & 37.9 & 2.9 & 0.0 \\
\hline Store C & 40.2 & 37.3 & 2.9 & 0.0 \\
\hline Average & 42.8 & 39.5 & 3.3 & 0.0 \\
\hline \multicolumn{5}{|l|}{ Giant Food: } \\
\hline Store A & 43.2 & 39.4 & 3.8 & 0.0 \\
\hline Store B & 57.0 & 55.1 & .9 & 0.9 \\
\hline Store C & 58.1 & 55.2 & 2.9 & 0.0 \\
\hline Average & 52.8 & 49.9 & 2.5 & 0.3 \\
\hline \multicolumn{5}{|l|}{ Grand Union: } \\
\hline Store A & 27.6 & 23.5 & 4.1 & 0.0 \\
\hline Store B & 27.3 & 25.3 & 2.0 & 0.0 \\
\hline Store C & 29.1 & 26.2 & 2.9 & 0.0 \\
\hline Average & 28.0 & 25.0 & 3.0 & 0.0 \\
\hline
\end{tabular}


ancludes mixed pricing where more than 1 price was found on shelf stock and instances where no marked prices were found.

*None of the differences in frequency of price difference were statistically significant; i.e., there was a 10 -percent probability that the differences could have occurred by chance.

*** All special competitive zones were located in higher income areas. No significance should be attached to the ordering of the stores within the chain. Stores with identical letters of different chains are not always in the same special competitive area.

Source: FTC Survey.

\section{Household Furnishings and Appliances}

The Bureau of Economics undertook also to develop information on purchases of "big ticket" appliances and household furnishings where access to installment credit is often a prerequisite of purchase. Of the 96 retailers surveyed, 65 indicated regular use of consumer installment contracts. Of those 65,18 were found to specialize in serving low-income customers.

Since direct data were not available on income of customers served by various stores, two criteria were used to identify retailers serving low-income customers: (1) location of store and (2) advertising practices. Stores located in low-income areas and doing no city-wide advertising were classified as low-income market retailers. Those located in higher income areas or using city-wide advertising media were classified as general market retailers.

A striking characteristic of low-income market retailers is the high proportion of their total sales accounted for by installment contract transactions. Table 4 indicates that installment credit transactions accounted for 93 percent of the total sales of the 18 low-income market retailers.

In addition to obtaining information on the use of installment credit, the Commission survey requested financial data as well as wholesale and retail prices on popular appliance and furniture items. This information was classified by type of retailer and indicated that operating results for low-income market retailers differed significantly from those for general market retailers in a number of important respects.

Although gross margins for different types of retailers in the survey sample varied, the most significant variation was found when margins of low-income market retailers were compared with those market retailers (Table 5). The 18 low-income retailers had an average gross margin of 60.8 percent. The average for general market retailers was 37 percent, ranging from a low of 30 percent for appliance, radio, and TV stores to a high of 41 percent for furniture and home furnishings. 9

Obviously, the higher the gross margin on a particular product, the higher will be its retail price. On the average, goods purchased for $\$ 100$ at wholesale sold for $\$ 255$ in low-income market stores, whereas the retail price was $\$ 159$ in general market stores (Figure 1). Thus, low-income market retailers marked up their cost $21 / 2$ times to determine their selling price. This was the average for the 18 low-income market retailers in the sample. The retailer with the largest volume of sales means that he marked up his merch andise on the average of more than three times his cost. 10 
TABLE 4. VALUE OF INSTALLMENT CONTRACTS AS A PERCENT OF SALES, DISTRICT OF COLUMBIA RETAILERS, 1966

\begin{tabular}{|c|c|c|c|c|c|}
\hline \multirow[b]{2}{*}{ Type of Retailer } & \multirow[b]{2}{*}{$\begin{array}{l}\text { Number of } \\
\text { Companies }\end{array}$} & \multirow[b]{2}{*}{$\begin{array}{c}\text { Net Sales } \\
(\$ 000)\end{array}$} & \multicolumn{3}{|c|}{ Installment Contracts: } \\
\hline & & & $\begin{array}{l}\text { Value } \\
(\$ 000) \\
\end{array}$ & $\begin{array}{l}\text { Percent } \\
\text { of Total }\end{array}$ & $\begin{array}{l}\text { As Percent } \\
\text { of Net Sales }\end{array}$ \\
\hline $\begin{array}{l}\text { Low-income market } \\
\text { retailers }\end{array}$ & 18 & 7,874 & 7,296 & 16.1 & 92.7 \\
\hline $\begin{array}{c}\text { General market retailers } \\
\text { Appliance, radio } \\
\text { and television }\end{array}$ & 47 & 143,096 & 37,955 & 83.9 & 26.5 \\
\hline $\begin{array}{l}\text { Furniture and home } \\
\text { furnishings } \\
\text { Department stores }\end{array}$ & $\begin{array}{r}22 \\
3\end{array}$ & $\begin{array}{l}26,643 \\
91,364\end{array}$ & $\begin{array}{l}10,608 \\
18,881\end{array}$ & $\begin{array}{l}23.5 \\
41.7\end{array}$ & $\begin{array}{l}39.8 \\
20.6\end{array}$ \\
\hline Total & $\underline{65}$ & 150,970 & 45,251 & 100.0 & 30.0 \\
\hline
\end{tabular}

Source: FTC Survey.

TABLE 5. NET SALES AND GROSS MARGINS OF DISTRICT OF COLUMBIA RETAILERS, 1966

\begin{tabular}{|c|c|c|c|c|c|}
\hline \multirow[b]{2}{*}{ Type of Retailer } & \multirow[b]{2}{*}{$\begin{array}{l}\text { Number of } \\
\text { Companies }\end{array}$} & \multicolumn{2}{|c|}{ Net Sales } & \multicolumn{2}{|c|}{ Gross Margin $^{a}$} \\
\hline & & $\begin{array}{l}\text { Value } \\
(\$ 000) \\
\end{array}$ & $\begin{array}{l}\text { Percent } \\
\text { of Total }\end{array}$ & $\begin{array}{l}\text { Value } \\
(\$ 000) \\
\end{array}$ & $\begin{array}{c}\text { As Percent } \\
\text { of Sales }\end{array}$ \\
\hline $\begin{array}{l}\text { Low-income market } \\
\text { retailers }\end{array}$ & 18 & $\underline{7,874}$ & $\underline{5.2}$ & $\underline{4,790}$ & 60.8 \\
\hline $\begin{array}{c}\text { General market retailers } \\
\text { Appliance, radio }\end{array}$ & $\underline{47}$ & 143,096 & 94.8 & $\underline{52,988}$ & 37.0 \\
\hline and television & 22 & 25,089 & 16.6 & 7,586 & 30.2 \\
\hline $\begin{array}{l}\text { Furniture and home } \\
\text { furnishings }\end{array}$ & 22 & 26,643 & 17.7 & 10,979 & 41.2 \\
\hline Department stores & 3 & 91,364 & 60.5 & 34,423 & 37.7 \\
\hline $\begin{array}{l}\text { Total, retailers using } \\
\text { installment contracts }\end{array}$ & 65 & $\underline{150,970}$ & 100.0 & $\underline{57,778}$ & 38.3 \\
\hline $\begin{array}{l}\text { Retailers not using } \\
\text { installment contracts }\end{array}$ & 31 & 74,842 & - & 26,902 & 35.9 \\
\hline $\begin{array}{l}\text { Total, all retailers } \\
\text { surveyed }\end{array}$ & 96 & 225,812 & - & 84,680 & 37.5 \\
\hline
\end{tabular}

${ }^{a}$ Gross margins reported by different types of retailers may not be strictly comparable. One low-income market retaile $r$ included finance charges and one general market appliance retailer included service charges in their net sales. Adjustments were made in these instances, but other retailers in the sample may have included such charges in their net sales and not reported their inclusion. To the extent that finance, service, and other charges might have been included in net sales and no corresponding adjustment made in cost of goods sold, gross margins for these retailers would be slightly overstated. However, every effort was made to calculate gross margins in this study net of finance and other charges.

Source: FTC Survey. 
LOW - INCOME MARKET RETAILERS

GENERAL MARKET RETAILERS :

APPLIANCE, RADIO \& TELEVISION STORES

FURNITURE \& HOME FURNISHING STORES

DEPARTMENT STORES

ALL RETAILERS USING INSTALLMENT CONTRACTS

RETAILERS NOT USING INSTALLMENT CONTRACTS

ALL RETAILERS SURVEYED

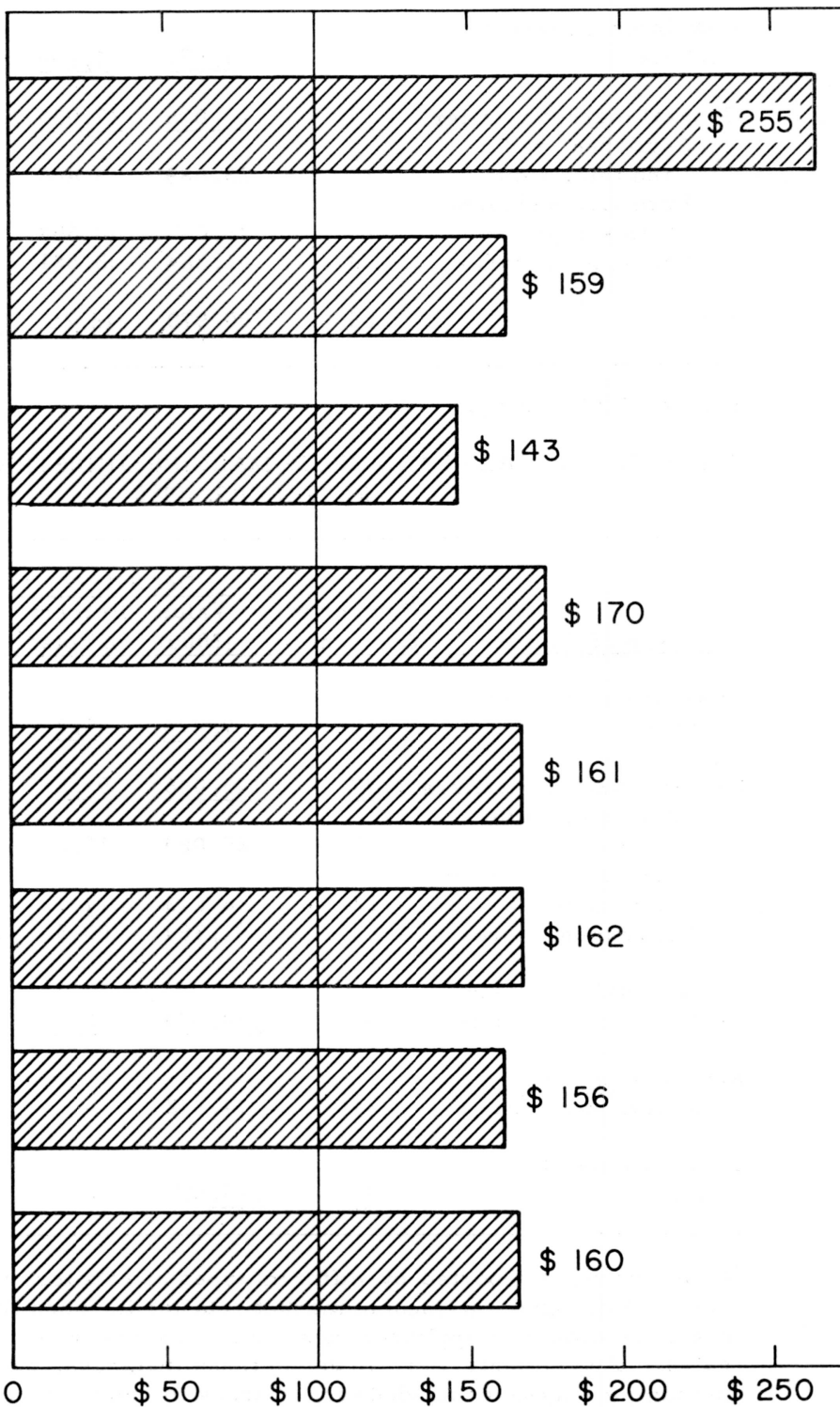

FWHOLESALE COST 1 GROSS MARGIN

AVERAGE SELLING PRICE, ASSUMING \$I WHOLESALE COST, BY TYPE OF RETAILE 
Perhaps the striking differences between the low-income market and the general market may best be illustrated by a comparison of prices for similar (in some cases identical) products. Table 6 matches similar makes and models of appliances sold by low-income market retailers and general market retailers.

TABLE 6. COMPARISONOF REPOR TED WHOLESALE AND RETAIL PRICES FOR BEST-SELLING PRODUCTS, LOW-INCOME MARKET AND GENERAL MARKET RETAILERS

\begin{tabular}{|c|c|c|c|c|}
\hline \multirow{4}{*}{ Products } & \multicolumn{2}{|c|}{ Wholesale Cost } & \multicolumn{2}{|c|}{ Retail Price ${ }^{a}$} \\
\hline & Low-Income & General & Low-Income & General \\
\hline & Market & Market & Market & Market \\
\hline & Retailer & Retailer & Retailer & Retailer \\
\hline \multicolumn{5}{|l|}{ Television sets: } \\
\hline Motorola portable & $\$ 109.00$ & $\$ 109.50$ & $\$ 219.95$ & $\$ 129.95$ \\
\hline Philco portable & 108.75 & 106.32 & 199.95 & 129.95 \\
\hline Olympic portable & $90.00^{\mathrm{b}}$ & 85.00 & 249.95 & 129.95 \\
\hline Admiral portable & 94.00 & 91.77 & 249.95 & 129.99 \\
\hline \multicolumn{5}{|l|}{ Radio: } \\
\hline Emerson & 16.50 & 16.74 & 39.95 & 25.00 \\
\hline \multicolumn{5}{|l|}{ Stereo: } \\
\hline Zenith & 32.99 & 32.99 & 99.95 & 36.99 \\
\hline \multicolumn{5}{|l|}{ Automatic washers: } \\
\hline Norge & 144.95 & 140.00 & 299.95 & 155.00 \\
\hline General Electric & 183.50 & 160.40 & 339.95 & 219.95 \\
\hline \multicolumn{5}{|l|}{ Dryers: } \\
\hline Norge & 80.00 & 87.00 & 249.95 & 102.45 \\
\hline General Electric & 206.90 & 205.00 & 369.95 & 237.76 \\
\hline Admiral & 112.00 & 115.97 & 299.95 & 149.95 \\
\hline \multicolumn{5}{|l|}{ Vacuum cleaners: } \\
\hline Hoover upright & 39.95 & 39.95 & 79.95 & 59.95 \\
\hline Hoover canister & 26.25 & 24.55 & 49.95 & 28.79 \\
\hline
\end{tabular}

${ }^{a}$ Retail prices are cash and do not include separately imposed finance charges.

${ }^{b}$ Reported as approximate wholesale cost.

Source: FTC Survey.

The general conclusion that emerges from these data is that the low-income market is a very expensive place to buy durable goods. On television sets (most of which are the popular 19-inch black and white portables), the general market retail price is about $\$ 130$. In the low-income market, a customer can pay up to $\$ 250$ for similar sets. Other comparisons include a dryer selling for $\$ 149.95$ from a general market retailer and for $\$ 299.95$ from a low-income market retailer; and a vacuum cleaner selling for $\$ 59.95$ in the general market and $\$ 79.95$ in the low-income market. 
Over 90 percent of low-income market retailer sales were on an installment contract basis. Table 7 shows the distribution of all installment contracts by effective annual rate of finance charge for those retailers reporting charges on installment credit sales. The bulk of installment credit sales by low-income market retailers was at effective annual financing rates of 22 percent of more. Nearly half (48 percent) was at rates ranging from 26 to 33 percent.

TABLE 7. INSTALLMENT CONTRACTS DISTRIBUTED BY EFFECTIVE ANNUAL RATE OF FINANCE CHARGE (ASSIGNED AND UNASSIGNED) $^{a}$

\begin{tabular}{|c|c|c|c|c|c|c|}
\hline \multirow{3}{*}{$\begin{array}{l}\text { Effective Annual } \\
\text { Rate of Finance } \\
\text { Charge (Percent) }\end{array}$} & \multicolumn{6}{|c|}{ Value of Contracts at Each Effective Annual Rate For: } \\
\hline & \multicolumn{2}{|c|}{$\begin{array}{c}\text { Low-Income } \\
\text { Market Retailers }\end{array}$} & \multicolumn{2}{|c|}{$\begin{array}{c}\text { General } \\
\text { Market Retailers }\end{array}$} & \multicolumn{2}{|c|}{$\begin{array}{l}\text { All Retailers } \\
\text { Combined }\end{array}$} \\
\hline & $\begin{array}{l}\text { Value of } \\
\text { Contracts } \\
(\$ 000)\end{array}$ & $\begin{array}{l}\text { Percent } \\
\text { of Total }\end{array}$ & $\begin{array}{c}\text { Value of } \\
\text { Contracts } \\
(\$ 000)\end{array}$ & $\begin{array}{l}\text { Percent } \\
\text { of Total }\end{array}$ & $\begin{array}{c}\text { Value of } \\
\text { Contracts } \\
(\$ 000)\end{array}$ & $\begin{array}{l}\text { Percent } \\
\text { of Total }\end{array}$ \\
\hline 33 & 360 & 7.1 & - & - & 360 & 0.8 \\
\hline 29 & 283 & 5.6 & 99 & 0.3 & 382 & 0.9 \\
\hline 27 & 1,087 & 21.6 & - & - & 1,087 & 2.5 \\
\hline 26 & 685 & 13.6 & - & - & 685 & 1.6 \\
\hline 24 & - & - & 3,541 & 9.3 & 3,541 & 8.2 \\
\hline 23 & - & - & 4,576 & 12.1 & 4,576 & 10.6 \\
\hline 22 & 871 & 17.3 & 1,173 & 3.1 & 2,044 & 4.8 \\
\hline 20 & - & - & 16,872 & 44.4 & 16,872 & 39.2 \\
\hline 18 & 1,550 & 30.8 & 173 & 0.5 & 1,723 & 4.0 \\
\hline 17 & - & - & 6,311 & 16.6 & 6,311 & 14.7 \\
\hline 16 & - & - & 77 & 0.2 & 77 & 0.2 \\
\hline 15 & 187 & 3.7 & 3,210 & 8.5 & 3,397 & 7.9 \\
\hline 14 & - & - & 460 & 1.2 & 460 & 1.1 \\
\hline 13 & - & - & 115 & 0.3 & 115 & 0.3 \\
\hline 11 & 14 & 0.3 & 635 & 1.7 & 649 & 1.5 \\
\hline Rate not available & - & - & 713 & 1.8 & 713 & 1.7 \\
\hline Total & 5,037 & 100.0 & 37,955 & 100.0 & 42,992 & 100.0 \\
\hline
\end{tabular}

\footnotetext{
ancludes all installment contracts for which separate finance charges were specified.
}

Source: FTC Survey. 
Contracts arising from sales by general market retailers rarely entailed such high charges. Three-fourths were at finance rates of 20 percent or less. This figure is heavily weighted by department store installment credit sales. Less than one percent of general market retailer contracts had finance charges exceeding 24 percent.

Among general market retailers, only appliance stores had rates consistently exceeding 20 percent. These retailers assigned most of their contracts at effective annual rates of 23 to 24 percent. Thus, virtually all of the contracts involving rates exceeding 24 percent were written by low-income market retailers.

Despite higher prices and more often than not higher finance charges, lowincome market retailers as a group do not appear to be unusually profitable. It is true that they reported the highest profit after taxes on net sales, 4.7 percent, as compared to 4.6 percent for general market department stores, 3. 9 percent for home furnishings, and 2.1 percent for appliances (Table 8). However, return on net worth for low-income market retailers was only 10.1 percent as compared to a range of 13 to 20 percent for the various groups of retailers serving the general market.

TABLE 8. NET PROFIT AFTER TAXES AS A PERCENT OF SALES AND RATES OF RETURN AFTER TAXES FOR DISTRICT OF COLUMBIA RETAILERS SURVEYED, 1966

\begin{tabular}{llc} 
& \multicolumn{1}{c}{ Net Profit } & Rate of \\
Type of Retailer & After Taxes as a & Return After Taxes \\
Percent of Sales & on Stockholders' Equity
\end{tabular}

Low-income market retailers

4. 7

10.1

General market retailers:

Appliance, radio and

television stores

Furniture and home

furnishings stores

Department stores

$\begin{array}{ll}2.1 & 20.3 \\ 3.9 & 17.6 \\ 4.6 & 13.0\end{array}$

Source: FTC Survey.

The findings of this study suggest that the marketing system for distribution of durable goods to low-income consumers is costly. Although their markups are very much higher than those of general market retailers, lowincome market retailers do not make particularly high net profits. They have markedly higher costs, partly because of high bad-dept expenses, but to a greater extent because of higher salaries and commissions as a percent of sales. These expenses reflect in part the greater use of door-to-door selling and expenses associated with the collection and processing of installment contracts.

The high prices charged by low-income market retailers suggest the absence of effective price competition. The competition that exists among low income market retailers apparently takes the form of easier credit availability rather than of lower prices. Greater credit risks are taken to entice cus- 
tomers. Insofar as the problem for low-income consumers is availability of credit, merchants who sell to them focus on this element.

\section{Approaches to Existing Problems}

Research by the Federal Trade Commission is one of a number of efforts that have served to increase our understanding of low-income consumer problems. ${ }^{11}$ Certainly, there is substantial agreement that special consumer problems surround the poor. We now know the answer to the question, Do the poor pay more? Research reveals also that no easy solution is at hand. Though it is often asserted that the poor pay more because of discrimination, the causes in fact are more complex. Study suggests that efforts to improve retail competition serving low-income consumers will be more effective in meeting their shopping needs than efforts designed to stop alleged discrimination.

Research emphasis relating to the low-income consumer should now shift . The fact that low-income consumers paymore has been fairly well established. We must move beyond a reiteration of this fact in our research efforts. Future research should take the direction of a search for solutions to the problem. This can be done in two ways. One is by an effort to further isolate the causal elements responsible for price differences which have been observed, particularly in the context of viewing the marketplace as a competitive process, rather than a problem in ethics. Secondly, a variety of experimental programs have been undertaken to aid low-income consumers. Economists should apply their skills to evaluating the workability of such programs, possible modifications, and prospects for long-run success.

Since much of the difficulty faced by the poor as consumers derives from imperfections in retailing competition, we should determine which imperfections are critical and, most important, amenable to change. With respect to dealing with problems involving credittransactions, the following suggestions have been made:

. . Every effortshould be made to make the poor consumer an informed consumer. Adult consumer education must be pressed. Some limited steps have already been taken through local community action programs, but only a beginning has been made. The poor consumer must be sufficiently informed to be a comparison shopper, aware of price differences for commodities purchased, and aware of differential finance charges..

Information alone, however, will not make the low-income consumer an effective comparison shopper, particularly when purchasing "big ticket" items. He must have access to credit on reasonable terms. Here, too, some steps have been taken. Limited experience with federally-sponsored credit unions in low-income areas indicates considerable reliability on the part of most borrowers. Loss rates have been low. The major problem appears to center on the need periodically to reschedule payments due to unanticipated unemployment or illness. Unfortunately, general market retailers appear to have been unsufficiently aggressive in reaching out to cultivate the low-income consumer. This conclusion seems amply justified when it is recalled that most customers of low-income market retailers repay on time despite the high prices and finance charges they must pay. Much needs to be done to develop alternatives to the easy credit merchant in financing installment purchases. 
Additionally, ways must be sought to shift the source of competition in low-income areas away from the granting of easy credit and toward providing good quality low-cost commodities. The major part of America's distribution system is highly competitive and price-conscious. Ways must be sought to incorporate the deprived sector of distribution into the main stream of activity. This, no doubt, involves not only efforts to encourage general market retailers to orient marketing efforts more specifically toward serving low-income consumers, but also steps to encourage the entrance of new competitors who will focus their competitive efforts on low cost merchandising. 12

With respect to food marketing, the Federal Trade Commission staff report suggesteda series of steps including federal efforts to induce new entry into low-income, inner-city markets. $13^{3}$

At the same time, the report noted:

Too little is known at the present time as to the most effective mix of public and private effort needed to improve marketing conditions for distributing food and other consumer products in low-income areas. Clearly, improvement is in order, as shown by this study and by an earlier study of household furnishings and appliances. Many new approaches to this problem, sponsored by both public and private agencies, are currently subject to experimentation. Certain older programs involving urban renewal and loan guarantee programs are being reevaluated and revised. 14

In the past several years, a variety of programs designed in some measure to deal with consumer problems of the poor have been initiated. Some are Government sponsored, some, private. The range of experimentation is wide, involving different cities and different emphases. It would seem that the time has come to catalogue these efforts carefully and to evaluate their impact. Research that revealed the successes and failures could go far in providing specific guidance to development of a coherent policy for dealing with a significant aspect of the problems. 
*Chief, Division of Industry Analysis, Bureau of Economics, Federal Trade Commission, Washington, D. C. Philip W. Jaynes of the Division of Industry Analysis reviewed this paper. His suggestions are greatly appreciated. The views expressed in this article are those of the author and do not necessarily reflect the views of the Bureau of Economics or of the Federal Trade Commission.

${ }^{1}$ Federal Trade Commission, Economic Report on Installment Credit and Retail Sales Practices of District of Columbia Retailers, 1968. See also: Arthur T. Andersen, "Installment Credit and the Low Income Consumer: A Case Study, "Quarterly Economic Digest, June 1968.

${ }^{2}$ Federal Trade Commission, Economic Report on Food Chain Selling Practices in the District of Columbia and San Francisco, 1969. (Hereafter referred to as "Food Chain.").

${ }^{3}$ See for example: Cleveland Consumer Protect Hearings, March 1971. It is interesting to note that this recent FTC summary of complaints of consumers living in low-income neighborhoods of Cleveland do not mention price variations associated with the issuance of welfare payments and food stamps.

${ }^{4}$ Food Chain, op. cit., p. 3.

${ }^{5}$ The price differential is supported, in part, by different buying habits of low-income purchasers, with limited transportation, who prefer or are forced to buy smaller, higher-cost containers.

${ }^{6}$ See also Food Marketing in Low Income Areas, Cooperative Extension Service, The Ohio State University. Columbus, Ohio, was the object of research in this study.

${ }^{7}$ Food Chain, op. cit. , p. 17.

${ }^{8}$ Food Chain, op. cit. , Table IV-5, p. 30.

${ }^{9}$ Subjecting these differences to statistical analysis indicated that the re was only one chance in 100 that they reflected simple random variation. In other words, there is every reason to believe that differences in gross margins of low-income market retailers and general market retailers are systematic.

${ }^{10}$ General market retailers that used no installment contracts were also contacted in the survey and their gross margins, as indicated in Table 5, did not differ significantly from the average general market retailers.

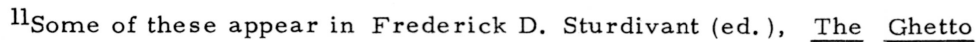
Market Place, The Free Press: New York, 1969.

${ }^{12}$ Arthur T. Andersen, op. cit.

${ }^{13}$ Federal Trade Commission, Food Chain, op. cit., pp. 10-12.

14 Ibid. 